\title{
Biotechnological valorization of cashew apple juice for the production of citric acid by a local strain of Aspergillus niger LCFS 5
}

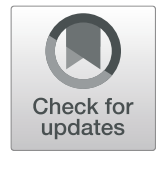

\author{
Adekunle Olusegun Adeoye ${ }^{1}$ and Agbaje Lateef ${ }^{2^{*}}$ (D
}

\begin{abstract}
Background: This work investigates the production of citric acid from cashew apple juice, an abundant waste in the processing of cashew, using a local strain of Aspergillus niger and the application of the citric acid as a coagulant for the production of soy cheese. Fungal isolates were obtained from a cashew plantation in Ogbomoso, Nigeria, using potato dextrose agar. Further screening was undertaken to determine the qualitative strength of acid production by the fungi on Czapek-Dox agar supplemented with bromocresol green, with the development of yellow zone taken as an indication of citric acid production. Thereafter, the best producing strain was cultivated in a cashew apple juice medium.

Results: Out of 150 fungal isolates generated from the cashew plantation, 92 (61.3\%), 44 (29.3\%) and 14 (9.3\%) were obtained from cashew fruits, soil and cashew tree surfaces, respectively. Different strains of fungi isolated include Aspergillus niger, A. flavus, A. foetidus, A. heteromorphus, A. nidulans and A. viridinutans. The isolates produced yellow zonation of $0.4-5.5 \mathrm{~cm}$ on modified Czapek-Dox agar; the highest was observed for a strain of $A$. niger LCFS 5 , which was identified using molecular tools. In the formulated cashew apple juice medium, the citric acid yield of LCFS 5 ranged 16.0-92.8 $\mathrm{g} / \mathrm{l}$ with the peak obtained on the 10th day of fermentation. The citric acid produced was recovered using the double precipitation method with $\mathrm{Ca}(\mathrm{OH})_{2}$ and $\mathrm{H}_{2} \mathrm{SO}_{4}$ having $\approx 70 \%$ purity of citric acid on HPLC. The citric acid acted as a coagulant to produce soy cheese with $66.67 \%$ acceptability by panelists.
\end{abstract}

Conclusion: This work has extended the frontiers of valorization of cashew waste by a strain of $A$. niger to produce citric acid in high yield, with potential application in food industries.

Keywords: Aspergillus niger, Cashew apple juice, Cheese, Citric acid, Fermentation, Valorization

\section{Background}

The knowledge of microbial biotechnology has aided the utilization of microorganisms for the production of enzymes, vaccines and disease diagnostic tools and the development of new industrial catalysts and products from fermentation that include organic acids [45]. The development of new microbial agents for products of importance to human being was dated to the era of traditional

\footnotetext{
* Correspondence: agbaje72@yahoo.com; alateef@lautech.edu.ng ${ }^{2}$ Laboratory of Industrial Microbiology and Nanobiotechnology, Department of Pure and Applied Biology, Ladoke Akintola University of Technology, PMB, 4000 Ogbomoso, Nigeria

Full list of author information is available at the end of the article
}

microbial biotechnology [23]. For thousands of years, microorganisms have been used to produce products such as bread, beer and wine. Understanding of control fermentation during the World War I resulted in the development of the acetone-butanol and glycerol fermentation, and from similar processes, the discovery of citric acid production was achieved [13,23]. Filamentous fungi are extensively used in the fermentation industry for the synthesis of numerous products that include enzymes, functional foods and organic acids $[2,12,28,46-48]$ and more recently in nanobiotechnology to produce nanoparticles [29-31]. One of the most important is the

\section{Springer Open}

(c) The Author(s). 2021 Open Access This article is licensed under a Creative Commons Attribution 4.0 International License, which permits use, sharing, adaptation, distribution and reproduction in any medium or format, as long as you give appropriate credit to the original author(s) and the source, provide a link to the Creative Commons licence, and indicate if changes were made. The images or other third party material in this article are included in the article's Creative Commons licence, unless indicated otherwise in a credit line to the material. If material is not included in the article's Creative Commons licence and your intended use is not permitted by statutory regulation or exceeds the permitted use, you will need to obtain permission directly from the copyright holder. To view a copy of this licence, visit http://creativecommons.org/licenses/by/4.0/. 
fungus Aspergillus niger, used industrially for the production of organic acids [3, 20, 37, 49, 74].

Many microorganisms have been screened for the production of citric acid including bacteria such as Bacillus licheniformis, B. subtilis and Corynebacterium spp. [43] and fungi such as Aspergillus niger, A. awamori and A. foetidus as well as some strains of Penicillium such as $P$. simplicissinum and $P$. restricium $[3,10,40,60]$. Yeasts such as Candida lipolytica, C. intermidia, Yarrowia lipolytica, Candida tropicalis, Pichia kluyveri and Saccharomyces cerevisiae [13, 18, 19, 39] have also been used to produce citric acid.

Among industrially important microorganisms are the Aspergilli; they are a fascinating group of fungi that exhibit immense ecological and metabolic diversity [22]. Out of the group, A. niger is regarded as safe with a GRAS status by the US Food and Drugs Administration under the Federal Food, Drug and Cosmetic Act [24, 61, 62]. A. niger is used as cell factory for a wide range of commercial enzymes as well as the production of millions of tons of organic acids [16]. It is easy to handle and has the ability to ferment a variety of cheap raw materials to produce citric acid with potentials of high yield $[3,57,66,70]$.

Citric acid has immense applications in different industries that include the production of foods, drinks and pharmaceuticals $[73,75]$. It is accepted as an acidulant and preservative that can be consumed in large quantities due to its low toxicity. Citric acid is produced in large amount and it is the next largest fermentation product after ethanol [72]. Its global demand was in excess of 2 million tons in 2015 [20], which requires innovative approaches for production through fermentation to meet the increasing demand. The global value of citric acid was estimated at $\$ 3.6 \mathrm{~b}$ in 2020 [15]. $\mathrm{Hu}$ et al. [41] summarized the strategies to enhance the efficient production of citric acid, and these include continuous screening for producers, production of high yielding mutants, exploitation of low-cost substrates, metabolic engineering and optimization of the fermentation process. Thus, the production of citric acid through fermentation will continue to be a hotbed of scientific endeavours. Several cheap agro-industrial wastes that include cassava peel, banana peel, rice straw, orange peel, sugarcane bagasse, chicken feather and pomegranate peel among others have been employed for the microbial production of citric acid $[3,27,53,57,60]$. It is envisaged that the list of agrowastes employed in citric acid production will be on the increase as researches in this area progress.

In Nigeria, cultivation of cashew (Anacardium occidentale) (Fig. 1) is on large scale with the production of cashew nut estimated at 100,000 tonnes [32] and world production standing at 3.96 million tonnes [69]. The

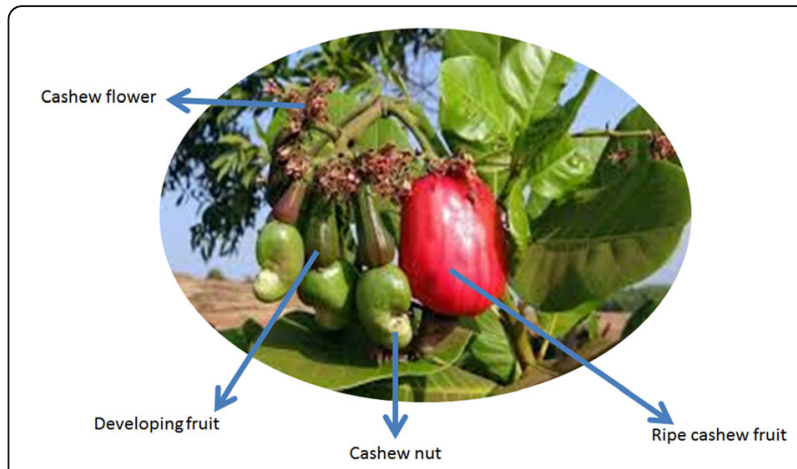

Fig. 1 Cashew plant showing the cashew apple fruit

harvesting and processing of cashew nut generate a lot of wastes, which include cashew apple juice, shell, press cake and nut shell liquid [33, 52, 59, 65]. When the fruit matures, the nut falls off the tree with the apple that contains the juice. In actual fact, only about $30 \%$ of apple fruit is consumed as food, the remaining $70 \%$ goes as waste [42]. The fruit is limited in human consumption by the astringency of the juice due to the high occurrence of tannin that it contains and high perishability $[21,55]$. This necessitates the need to valorize the wastes for biotechnological production of valuable products. The cashew apple bagasse and juice have been used to produce bioproducts such as biohydrogen, biosurfactants and bioelectricity [33, 54, 67].

The cashew apple juice constitutes about $90 \%$ of the weight of the leftover after the removal of the nut from the whole fruit [54]. The richness of the juice in nutrients [7] makes it an ideal complex medium for microbial growth, which can be explored in the production of citric acid. This innovative approach seeks to add value to cashew production to valorize the apple juice to produce valuable bioproduct (citric acid) that is in high demand worldwide, to reduce the burden of environmental pollution and creation of breeding sites for insects and pathogens occasioned by indiscriminate on-the-farm disposal of apple pomace. Apple juice has been previously explored to produce oligosaccharides, ethanol and oxalic acid through fermentation [14, 56, 68]. In this study, new isolates of Aspergillus niger obtained locally from a cashew farm were evaluated for the production of citric acid using cashew apple juice. The biotechnological application of the citric acid produced was investigated in the production of cheese.

\section{Methods}

\section{Isolation of fungi}

The fungal isolates were obtained from cashew apple fruit, the soil and the bark of cashew trees growing on the cashew plantation of LAUTECH Teaching and 
Research Farm, Ogbomoso, Nigeria. Isolation from the fruit and tree bark was done by wiping moistened sterile swabs, over a surface measured approximately $8 \mathrm{~cm}^{2}$ and inoculated on potato dextrose agar (PDA) plates, while the soil sample was serially diluted, and aliquot used as the inoculum. To prevent bacterial growth, 30 $\mathrm{mg} / \mathrm{l}$ streptomycin was added to the medium, and rosebengal stain was added to prevent faster spore production. The plates were incubated for 7 days at room temperature $\left(30 \pm 2{ }^{\circ} \mathrm{C}\right)$. Later, every reproduced fungal colony was sub-cultured into PDA, Sabouraud dextrose agar (SDA) and Czapek-Dox agar (CZA). These plates were incubated for 7 days at room temperature to obtain the pure cultures of the micro-fungi. The fungi were cultured in an agar slant of PDA and periodically subcultured at intervals of two. The cultures were stored at $4{ }^{\circ} \mathrm{C}$ until required.

\section{Screening of fungal isolates for citric acid production}

The fungal isolates were screened qualitatively in a Petri dish for the production of citric acid using Czapek-Dox agar that was supplemented with $5 \mathrm{ml}$ of $5 \%$ bromocresol green as an indicator. The isolates were inoculated on the plates by inoculating needle using hyphae from a 48-h-old culture and grown at $30 \pm 2{ }^{\circ} \mathrm{C}$ for 5 days. The production of the yellow zone around the colony was taken as a measure of the ability to produce citric acid, due to the lowering of $\mathrm{pH}$ to acidic values [39], and used to rank the fungi by measuring the diameter of the zones. The fungal strains that produced yellow zonation were chosen for further work.

\section{Characterization and identification of the fungal isolates}

The fungal isolates that gave positive results for the production of citric acid in the bromocresol green plate assay were characterized both macroscopically and microscopically. The morphology of the fungi was studied on PDA, while few strands of mycelia were observed under the microscope upon staining with lactophenol cotton blue and identified following standard scheme [26]. The best citric acid-producing strain of Aspergillus niger was further characterized using molecular technique employing ITS4 (5'-TCCTCCGCTTATTGATAT GC-3') and ITS5 (5' -GGAAGTAAAAGTCGTAACAA GG-3') primers [76], following standard protocols [1]. The PCR products were resolved using agarose gel electrophoresis and also sequenced using a commercial facility. The sequences were aligned using BioEdit sequence software, and consensus sequences were deposited in GenBank of the National Centre for Biotechnology Information (http://www.ncbi.nlm.nih.gov/) to identify the isolate.

\section{Extraction and preparation of juice from cashew apple}

The cashew apples were collected and stored in the refrigerator prior to extraction of the juice at $4{ }^{\circ} \mathrm{C}$. They were sorted to remove defective apples. The selected apples were washed to remove dust, dirt and foreign particles. The apples were packed into a weighing can to determine the weight. The fruit juice was then extracted using a juice extracting machine (Cookworks Model no SJ13408 China) and centrifuged at $4000 \mathrm{rpm}$ for $30 \mathrm{~min}$. The clarified juice was then pasteurized at $60{ }^{\circ} \mathrm{C}$ for 30 min to denature enzymes that may cause autoxidation and browning reaction during pre-processing storage and to also make it sterile. Furthermore, $0.7 \mathrm{~g} / \mathrm{l}$ sodium metabisulfite was added to preserve the juice and stored in the refrigerator at $4{ }^{\circ} \mathrm{C}$ until use. Earlier, the sugar content of the juice was determined to ensure the maturity of the apple and prevent hypertonic solution that may hinder the growth of the organism by the use of a refractometer [51]. The concentration of sugar was diluted appropriately.

\section{Production and quantification of citric acid}

The fermentation medium was prepared as apple juice that was adjusted to $12{ }^{\circ}$ brix by addition of $10 \%$ sucrose and $\mathrm{pH}$ adjusted to 6.5 using $0.1 \mathrm{M} \mathrm{NaOH}$. The best fungal strain from the qualitative assay, LCFS 5 , was inoculated into the medium following an established procedure [3]. The cultures were incubated at $30 \pm 2{ }^{\circ} \mathrm{C}$ for 12 days during which the $\mathrm{pH}$, ${ }^{\circ}$ brix, total titratable acidity and citric acid yield were measured. At each harvest period, the culture was filtered using Whatman filter paper No. 1, and the filtrates used for the analyses. The titrimetric method was used to determine the yield of citric acid as previously described [6] by employing 0.1 $\mathrm{M} \mathrm{NaOH}$ and phenolphthalein. Briefly, 2-3 drops of phenolphthalein were added to $1 \mathrm{ml}$ of the filtrate which was titrated against with $0.1 \mathrm{M} \mathrm{NaOH}$ until the end point is reached with pink colour development. The citric acid yield was calculated thus [25]:

$$
\text { Citric acid }(\mathrm{g} / \mathrm{l})=0.64 \times \text { titre value; }
$$

Citric acid equivalent factor is $0.0064 \mathrm{~g} / \mathrm{l}$ of citric acid

The flowchart of the production of citric acid from cashew apple juice is depicted in Fig. 2.

\section{Purification of citric acid}

The fermenting broth was filtered using Whatman filter paper No. 1 to remove the fungal biomass. The citric acid in the filtrate was recovered by the double precipitation method $[44,50]$ using $\mathrm{Ca}(\mathrm{OH})_{2}$ and $\mathrm{H}_{2} \mathrm{SO}_{4}$ in a stepwise manner to separate citric acid from the fermenting broth. To $500 \mathrm{ml}$ of the filtrate, $30 \mathrm{~g}$ of $\mathrm{Ca}(\mathrm{OH})_{2}$ was added and agitated briefly at $60{ }^{\circ} \mathrm{C}$. The 


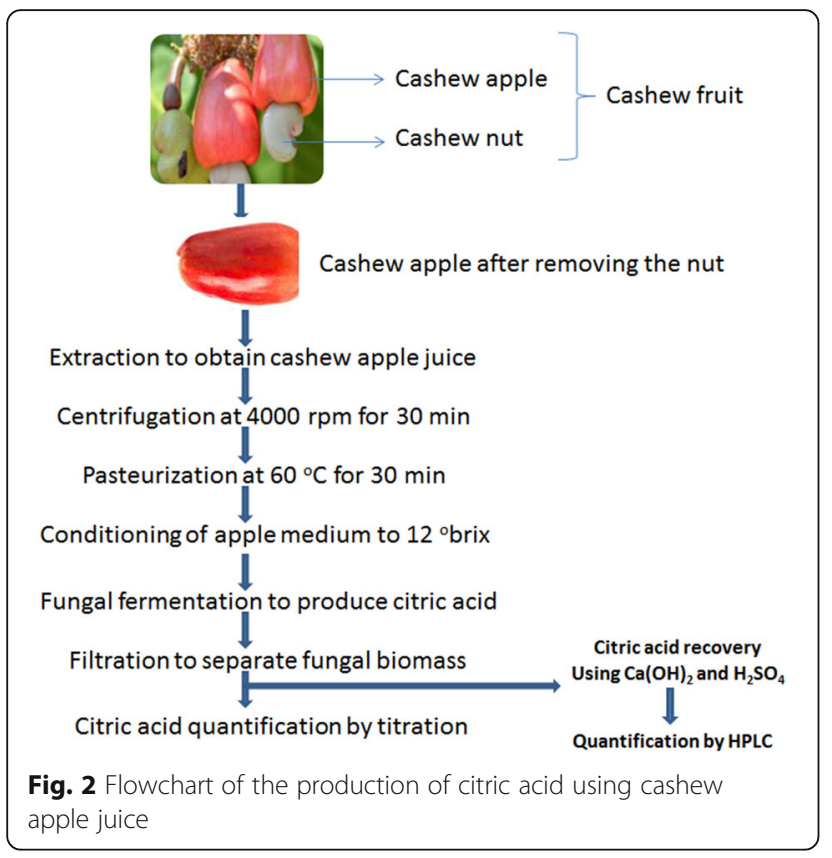

calcium citrate precipitate that was formed was recovered, diluted with distilled water (1:10) and further treated with conc. $\mathrm{H}_{2} \mathrm{SO}_{4}$ (10:1). The sequence of the recovery process of citric acid is depicted in Fig. 3. The quantification of the citric acid was done on HPLC Infinity 1260 (Agilent Technologies, USA) [5, 38] at a wavelength of $211 \mathrm{~nm}$ using a diode array detector (DAD). The citric acid (Sigma-Aldrich, Darmstadt, Germany) was prepared by dissolving $0.001 \mathrm{~g}$ in $10 \mathrm{ml}$ of sodium phosphate buffer and used as standard. Acetonitrile buffer at 70:30 (pH 6.5) was used as the mobile phase at a flow rate of $1.0 \mathrm{ml} / \mathrm{min}$. The temperature

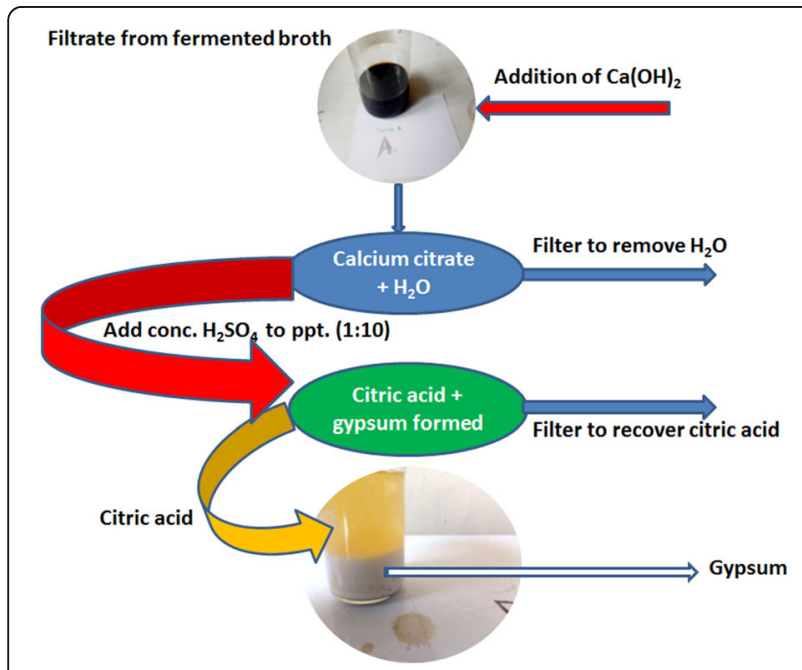

Fig. 3 Scheme for the recovery and purification of citric acid of the column (Primesep D, $100 \AA, 5 \mu \mathrm{m}, 4.6 \times 150 \mathrm{~mm}$ ) was maintained at $35{ }^{\circ} \mathrm{C}$ during the analysis.

Product development: use of citric acid as a coagulant to produce cheese

Soy cheese was produced using the citric acid obtained from the fungal fermentation of cashew apple juice through the modified methods of Gomaa et al. [36]. Locally procured soya beans were soaked in water $(1: 5)$ for $10 \mathrm{~min}$, after which the seed coat was removed manually. The soya bean was milled, mixed with water $(1: 16)$ and then sieved using muslin cloth. The filtrate obtained was poured into a clean container and boiled at $100{ }^{\circ} \mathrm{C}$ for $30 \mathrm{~min}$, during which citric was added to the boiling liquid until it coagulates, and there is separation of cheese from water. Typically, 16 parts of soy filtrate was treated with 1.2 parts of citric acid. The cheese was collected, pressed in muslin cloth to remove excess water, cut into pieces and steamed with the addition of salt to taste. The control cheese samples were produced using industrial citric acid $(0.1 \mathrm{~g} / \mathrm{ml})$, and unfermented cashew apple juice under the same condition. Both boiled and fried cheeses produced through this method were presented for sensory evaluation on a 9-point hedonic scale using University undergraduate students as panelists. Nine judges were arranged for sensory evaluation of the cheese produced, to assess qualities which include taste, colour, flavour and texture. The responses of the judges were analysed, and the multiple comparison test was done by employing an analysis of variance.

\section{Ethics approval and consent to participate \\ Not applicable}

\section{Results}

\section{Isolation of fungal species}

The sampling carried out in LAUTECH cashew plantation produced 150 fungal isolates which were grouped based on sources of isolation. The soil sample produced 44 (29.3\%) of the isolates identified, while fruit samples produced $92(61.3 \%)$ of the isolates and 14 (9.3\%) were derived from the tree surfaces. Following morphological studies, fungi that were isolated include Aspergillus niger, A. flavus, A. foetidus, A. heteromorphus, A. nidulans and $A$. viridinutans. Among the isolates, A. niger was frequently isolated. The growth of $A$. niger appeared whitish, cotton-like initially at about $24 \mathrm{~h}$ of inoculation (Fig. $4 a)$. The mycelia are slender, thread-like, which turned black or blackish-brown with age as shown in Fig. 4b and c. It bears black spores with colonies consisting of a compact white felt covered by a dense layer of dark brown to black conidial heads. Conidial heads were large, globose and dark brown (Fig. 4d), became radiated 

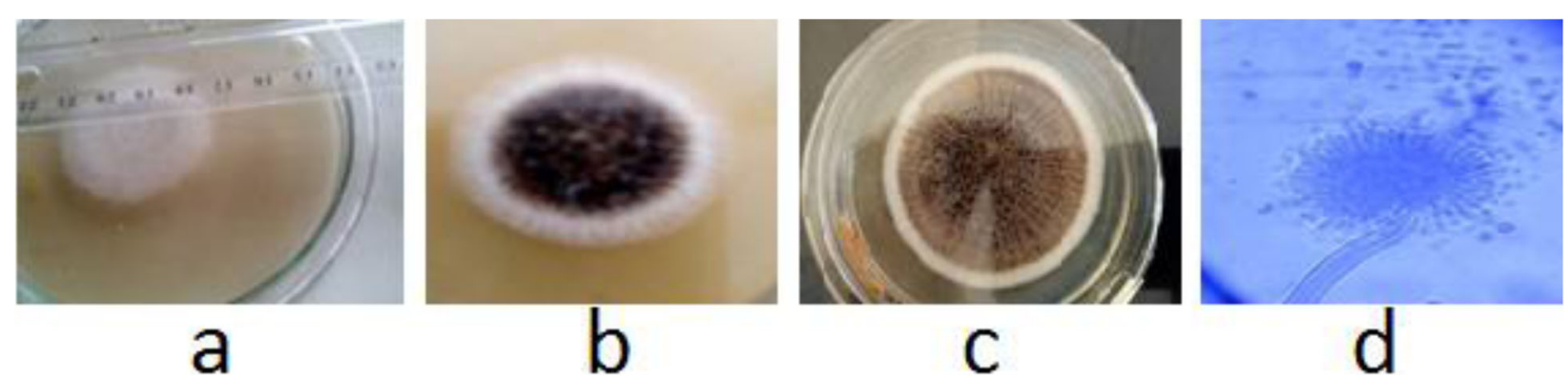

Fig. 4 The morphological characteristics of the isolated Aspergillus niger (a whitish cottony growth at 24 h; $\mathbf{b}$ black growth at 72 h; $\mathbf{c}$ loose column at 96 h; $\mathbf{d}$ microscopic view of the colonial head)

and tended to split into several loose columns with age as shown in Fig. 4c.

\section{Qualitative detection of production of citric acid by the fungal isolates}

The fungal isolates produced yellow zonation that ranged from 0.4 to $5.5 \mathrm{~cm}$ on CZA modified with bromocresol green, with a strain of $A$. niger LCFS 5 being the best producer of citric acid (Fig. 5). The strain has been identified through molecular technique and its sequence deposited in NCBI with the accession number MZ448204. The gel of PCR products of strain LCF 5 is presented in Fig. 6.

\section{Production of citric acid in cashew apple juice by aspergillus Niger LCFS 5}

In a fermentation period of 12 days, A. niger LCFS 5 produced 16.0-92.8 $\mathrm{g} / \mathrm{l}$ of citric acid, with the peak achieved at day 10 , and maintained on the 11th day before declining to $90.0 \mathrm{~g} / \mathrm{l}$ on the 12 th day (Table 1 ). The initial $\mathrm{pH}$ of the substrate was 6.5 ; it declined gradually to reach 2.40 on the 12th day due to the activities of the fermenting organism, while the degree Brix similarly declined during fermentation from the initial value of 12 to $3.8{ }^{\circ}$ brix on the 12th day. Conversely, total titratable acidity increased from 2.50 to reach the peak value of 14.5 on the 10th day of fermentation.

\section{Recovery and purification of citric acid}

The liquor obtained after fermentation was purified to separate citric acid from impurities as earlier shown in Fig. 3. The HPLC chromatogram of the citric acid is shown in Fig. 7, while Table 2 shows the presence of $69.912 \mu \mathrm{g} / \mathrm{ml}$ of citric acid at a retention time of 3.323 min, representing $\approx 70 \%$ composition of the liquor. Unidentified peaks $1-5$ had concentrations of 1.3835$12.9518 \mu \mathrm{g} / \mathrm{ml}$.

\section{Product development: use of citric acid as a coagulant to produce cheese}

The result of quality evaluation of soy cheese is presented in Fig. 8, which showed that sample A produced with the citric acid of A. niger LCFS 5 was consistently preferred by the panelists in terms of the texture, colour, flavour and firmness with a performance of $55.56-81.44 \%$. Samples B and C produced using industrial citric acid and unfermented cashew apple juice respectively, followed in terms of the quality.

\section{Discussion}

From the investigation, A. niger dominated isolation from the fruit possibly due to the presence of sugar and high moisture content. Several authors have reported frequent isolation of $A$. niger from diverse environmental and food samples $[11,35,63,64]$ including those related
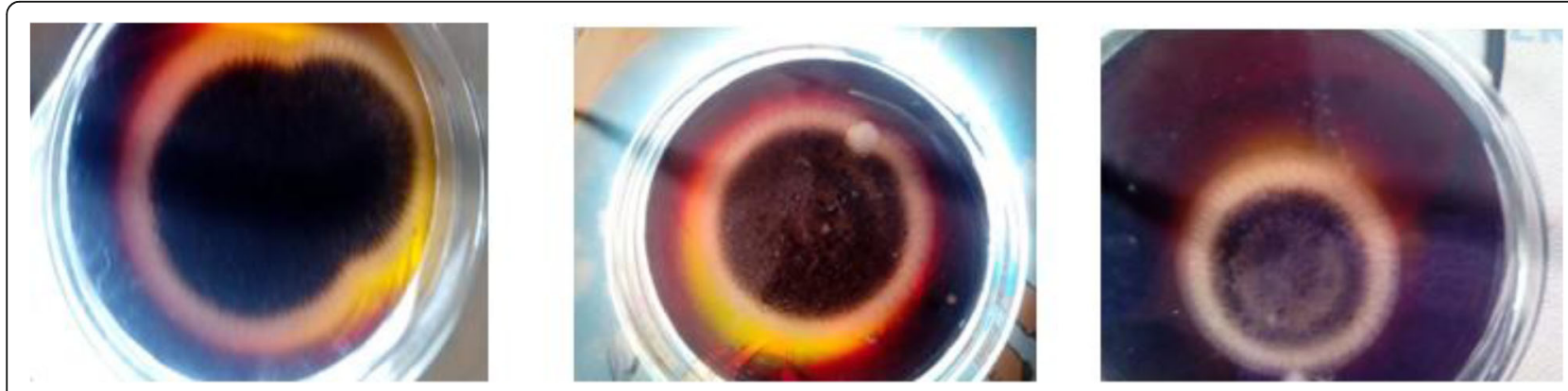

Fig. 5 Citric acid production by different strains of Aspergillus niger on bromocresol green Czapek-Dox agar showing yellow zonation 


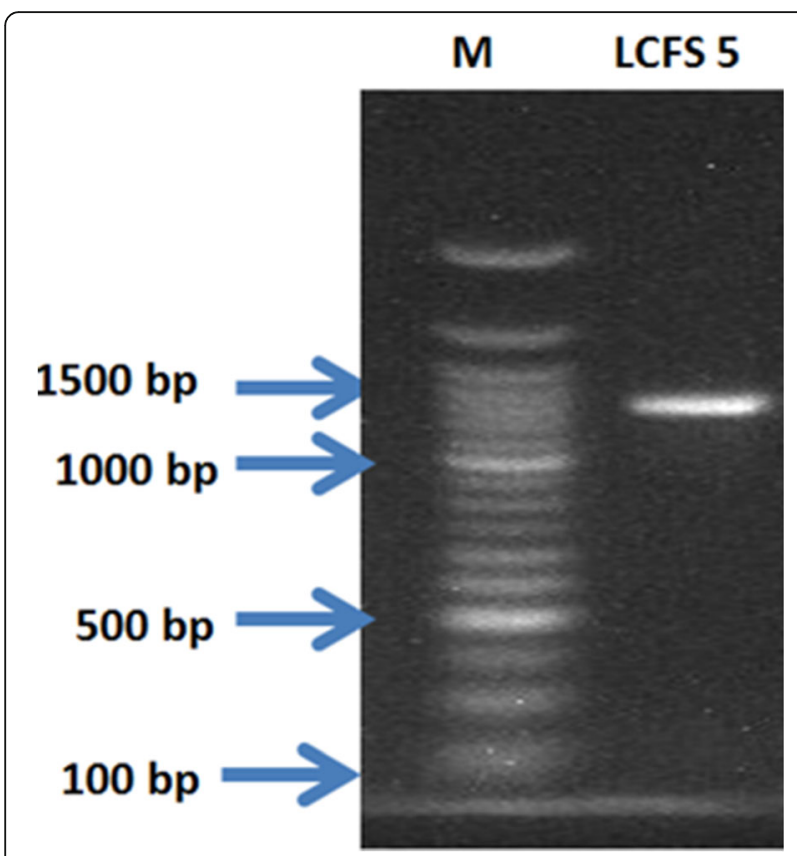

Fig. 6 The PCR product obtained via electrophoresis on 1.5\% agarose $\{\mathrm{M}$, marker; LCFS 5; genomic DNA of Aspergillus niger LCFS $5(M Z 448204)\}$

to cashew [4, 9]. The ability of $A$. niger to produce several hydrolyzing enzymes enables the fungus to utilize a wide range of complex substrates for growth and survival in diverse environments. The cultural morphology of the strains of $A$. niger was in agreement with those previously reported $[78,79]$ and thus was putatively identified as such.

The qualitative screening of production of citric acid by the fungal isolates was undertaken using the

Table 1 Quantitative determination of citric acid produced by A. niger LCFS 5 in the cashew apple juice medium

\begin{tabular}{lllll}
\hline Day of fermentation & $\mathbf{p H}$ & ${ }^{\circ}$ brix & TTA & Citric acid (g/l) \\
\hline 1 & 6.50 & 12.0 & 2.50 & 16.00 \\
2 & 5.40 & 10.5 & 3.70 & 23.70 \\
3 & 4.43 & 9.5 & 6.50 & 41.60 \\
4 & 4.33 & 8.0 & 7.10 & 45.44 \\
5 & 3.73 & 5.0 & 12.2 & 85.00 \\
6 & 3.70 & 5.0 & 12.2 & 85.00 \\
7 & 3.50 & 4.8 & 13.1 & 83.84 \\
8 & 3.48 & 4.7 & 13.5 & 86.40 \\
9 & 3.47 & 4.5 & 14.0 & 89.60 \\
10 & 3.44 & 4.2 & 14.5 & 92.80 \\
11 & 2.51 & 4.1 & 14.5 & 92.80 \\
12 & 2.40 & 3.8 & 14.1 & 90.00 \\
\hline
\end{tabular}

LCFS 5 LAUTECH Cashew Farm strain 5, TTA total titratable acidity; each value is an average of three readings bromocresol green method which has been used by various authors for the rapid screening of fungi for the production of citric. The extent of yellow zonation obtained in this work correlates with zonation of $0.2-9.0 \mathrm{~cm}$ previously reported $[3,39,58]$ for citric acid producers. The best producing strain $A$. niger LCFS 5 was selected for further work, and its molecular characterization confirmed the fungus as a strain of $A$. niger with accession number MZ448204, having a very high homologous sequence of $99.516 \%$ with established strains of $A$. niger in GenBank.

The copious production of citric acid by $A$. niger LCFS 5 to the extent of $92.8 \mathrm{~g} / \mathrm{l}$ in a cashew apple juice medium is outstanding. For a wild strain of $A$. niger, the yield obtained for LCFS 5 in this study is favourably higher than those previously reported for other strains of $A$. niger grown on different complex substrates such as cassava peel, African star apple peel, palm date, molasses and chicken feather peptone with a productivity of $1.93-68.8 \mathrm{~g} / \mathrm{l}[3,6,8,25,53,58]$. The good performance of $A$. niger LCFS 5 in producing high amount of citric acid in the cashew apple juice medium may not be unconnected with the richness of the juice in sugars, vitamins, minerals and amino acids [54] that promoted the growth of the fungus. The medium has been exploited for microbial production of ethanol, oligosaccharides, oxalic acid, single cell protein, biosurfactant and biohydrogen among others [14, 54, 56, 68]. Thus, the present study has extended the frontiers of valorization of cashew apple juice to produce citric acid via a biotechnological approach, which adds value to cashew cultivation, and has the potential to address the environmental nuisance that indiscriminate disposal of cashew apple constitutes. This report further lays credence to $A$. niger as a potent producer of citric acid, and strain LCFS 5 adds to the growing list of producer strains that may serve the purpose of extending frontiers in the industrial production of citric acid to meet the high demand for the product.

Citric acid produced by $A$. niger LCFS was successfully recovered through double precipitation and qualitatively detected and quantified using HPLC. While citric acid accounted for almost $70 \%$ of the organic acids produced, the five unidentified peaks with about $30 \%$ composition of the liquor may be attributed to other organic acids produced by the isolate. In addition to citric acid, $A$. niger is capable of producing itaconic, malic, kojic, succinic and gluconic acids [16, 77] as previously reported. The use of HPLC for quantification of organic acids is a wide practice, as authors have employed HPLC to quantify citric acid production through fungal fermentation with the reported purity of $61.90-65.61 \%$ [34, 71]. The result herein presented showed that $A$. niger LCFS 5 has 


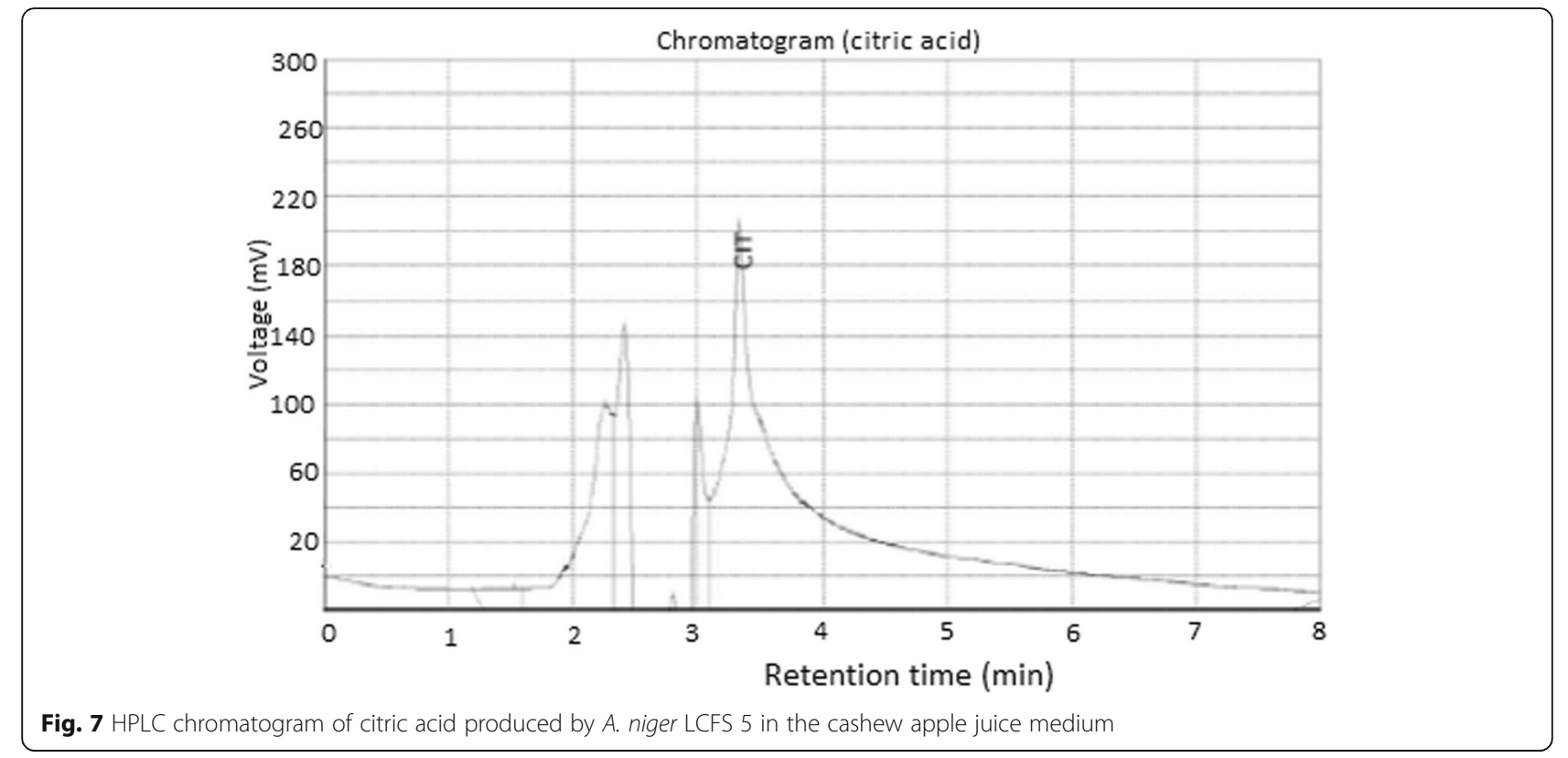

potential for production of citric acid in high titre and comparable to those earlier reported. Therefore, it can be efficaciously deployed for the production of citric acid.

One of the major applications of citric acid in food industry is its use as a coagulant [17]. Hence, the citric acid recovered was used to produce cheese from soy bean. Among the three samples produced using recovered citric acid synthesized by $A$. niger LCFS 5 (sample A), commercial citric acid (sample B) and unfermented cashew apple juice (sample C), sample A was preferred most by the nine panelists in terms of texture, colour, firmness and flavour, where it consistently scored higher than both samples A and B. While sample A had a general acceptance of $66.67 \%$, samples B and C had 55.27 and $39.44 \%$, respectively. The general acceptance of sample A might have been influenced by reduced astringency due to fungal fermentation of tannin in cashew apple juice, the impact of volatile compounds to improve flavour and the firmness that mimics the textural property of meat. Therefore, the citric acid produced by $A$. niger
LCFS 5 can find useful application in the production of soy cheese with acceptable attributes.

\section{Conclusions}

This work has established the production of citric acid from cashew apple juice using a high-yielding local strain of $A$. niger, thereby extending the frontiers of biotechnological valorization of wastes from cashew apple processing. The production yield of $92.8 \mathrm{~g} / \mathrm{l}$ by strain LCFS 5 within 10 days of fermentation is an appreciable yield when compared to those in previous works even under optimized conditions. Further analysis of the fermented cashew apple juice showed purity of the recovered acid at $69.91 \%$ showing that cashew apple juice will be a good substrate for the production of citric acid with an acceptable yield. The study has also shown that the utilization of citric acid for the production of cheese can serve as a veritable way of aiding local cheese production as the cheese produced has an acceptable level of $66.67 \%$. Hence, citric acid produced from the fermentation of citric acid can be used as a replacement

Table 2 Quantification of citric acid produced using HPLC

\begin{tabular}{cccccc}
\hline Peak No. & Peak ID & Ret Time & Height & Area & $\begin{array}{c}\text { Conc } \\
\mu \mathrm{g} / \mathrm{mL}\end{array}$ \\
\hline 1 & Unidentified & 1.523 & 44173.219 & 636328.125 & 1.3835 \\
2 & Unidentified & 2.265 & 248239.172 & 5957151.500 & 12.9518 \\
3 & Unidentified & 2.415 & 313055.219 & 2658349.250 & 5.7797 \\
4 & Unidentified & 2.807 & 166790.781 & 2403709.250 & 5.2261 \\
5 & Unidentified & 2.998 & 274061.188 & 2183337.250 & 4.7469 \\
6 & Citric acid & 3.323 & 366840.719 & 32155764.000 & 69.9120 \\
\hline
\end{tabular}




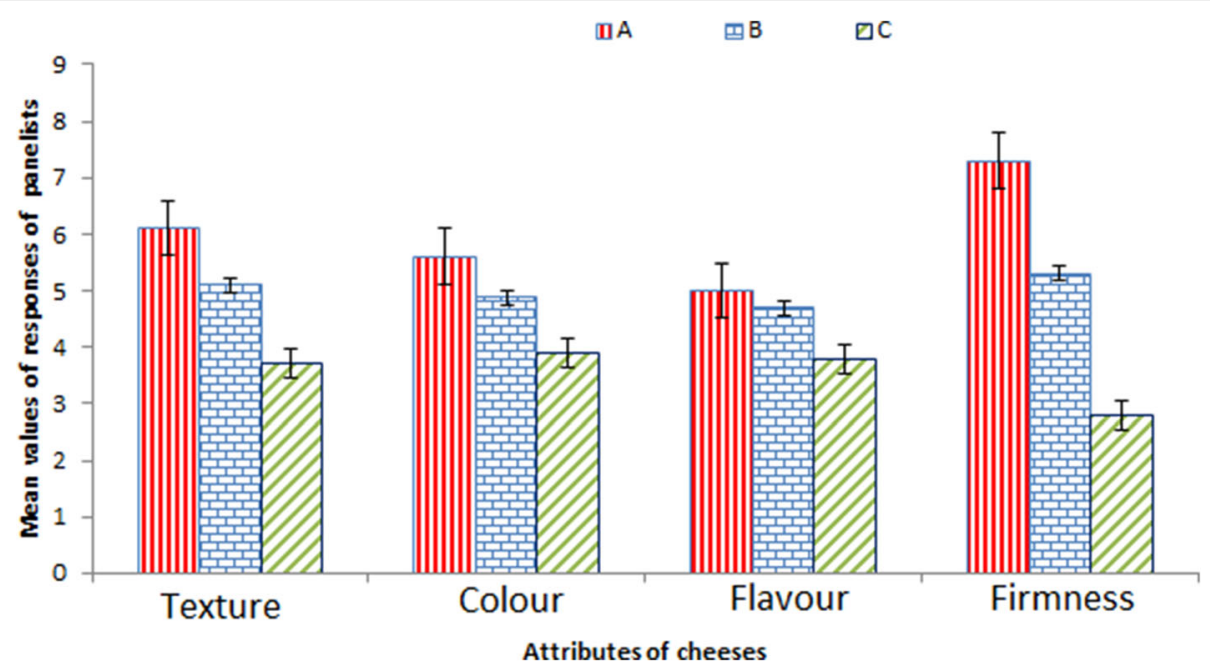

Fig. 8 Sensory evaluation of the cheese

coagulant for cheese production. This work represents an original contribution to the valorization of agrowastes to produce citric acid in high yield to meet the ever-increasing demand for citric acid worldwide.

\section{Abbreviations}

CZA: Czapek-Dox agar; HPLC: High-performance liquid chromatography; LCFS: LAUTECH Cashew Farm Strain; 'obrix: Degree Brix; PDA: Potato dextrose agar; SDA: Sabouraud dextrose agar; TTA: Total titratable acidity

\section{Acknowledgements}

The authors are grateful to LAUTECH, Ogbomoso, Nigeria, for the provision of some of the facilities used in this investigation

\section{Authors' contributions}

AL conceived and designed the work. AOA carried out the experiment and collected the data. Both authors jointly wrote the paper, read it and approved the final manuscript for publication.

\section{Funding}

The study did not receive fund from any organization, private or public.

\section{Availability of data and materials}

Data used in the experiment are presented in the article.

\section{Declarations}

Ethics approval and consent to participate

Not applicable

\section{Consent for publication}

Not applicable

\section{Competing interests}

The authors declare that they have no competing interests.

\section{Author details}

${ }^{1}$ Department of Food Science, Ladoke Akintola University of Technology, PMB, 4000 Ogbomoso, Nigeria. ${ }^{2}$ Laboratory of Industrial Microbiology and Nanobiotechnology, Department of Pure and Applied Biology, Ladoke Akintola University of Technology, PMB, 4000 Ogbomoso, Nigeria.
Received: 28 June 2021 Accepted: 21 August 2021

Published online: 17 September 2021

\section{References}

1. Adebayo EA, Oloke JK, Yadav A, Barooah M, Bora TC (2013) Improving yield performance of Pleurotus pulmonarius through hyphal anastomosis fusion of dikaryons. World J Microbiol Biotechnol 29(6):1029-1037. https://doi.org/1 0.1007/s11274-013-1266-8

2. Adeeyo AO, Lateef A, Gueguim-Kana EB (2016) Optimization of the production of extracellular polysaccharide from the shiitake medicinal mushroom Lentinus edodes (Agaricomycetes) using mutation and a genetic algorithm-coupled artificial neural network (GA-ANN). Int J Med Mushrooms 18(7):571-581. https://doi.org/10.1615/IntJMedMushrooms.v18.i7.20

3. Adeoye AO, Lateef A, Gueguim-Kana EB (2015) Optimization of citric acid production using a mutant strain of Aspergillus niger on cassava peel substrate. Biocatal Agric Biotechnol 4(4):568-574. https://doi.org/10.1016/j. bcab.2015.08.004

4. Adetunji MC, Ngoma L, Atanda OO, Mwanza M (2019) A polyphasic method for the identification of aflatoxigenic aspergilla from cashew nuts. World J Microbiol Biotechnol 35(1):15. https://doi.org/10.1007/s11274-018-2575-8

5. Agius C, von Tucher S, Poppenberger B, Rozhon W (2018) Quantification of sugars and organic acids in tomato fruits. MethodsX 5:537-550. https://doi. org/10.1016/j.mex.2018.05.014

6. Ajala AS, Adeoye AO, Olaniyan SA, Fasonyin OT (2020) A study on effect of fermentation conditions on citric acid production from cassava peels. Sci African 8:e00396. https://doi.org/10.1016/j.sciaf.2020.e00396

7. Akinnibosun Fl, Oyetayo AM (2018) Turning agricultural wastes to wealth in Nigeria: a review of cashew (Anacardium occidentale L.) peduncle (apple) potentials. Nigerian Res J Eng Environ Sci 3(1):57-64

8. Alhadithy DA, Yasin SR, Al-sa'ady JAR (2020) Optimum conditions for citric acid production from local Aspergillus niger $\mathrm{S} 11$ isolate by submerged fermentation. Ann Trop Med Health 23:232-134

9. Alrudainy AM, Mshari A (2020) Isolation and identification of fungi from some nuts products. Plant Archives 20(1):274-276

10. Angumeenal AR, Venkappayya D (2013) An overview of citric acid production. LWT-Food Sci Technol 50(2):367-370. https://doi.org/10.1016/j. Iwt.2012.05.016

11. Anupma A, Tamang JP (2020) Diversity of filamentous fungi isolated from some amylase and alcohol-producing starters of India. Front Microbiol 11: 905. https://doi.org/10.3389/fmicb.2020.00905

12. Bamigboye CO, Oloke JK, Dames JF, Burton M, Lateef A (2019) Optimization of the process for producing biomass and exopolysaccharide from the king tuber oyster mushroom, Pleurotus tuber-regium (Agaricomycetes), for biotechnological applications. Int J Med Mushrooms 21(4):311-322. https:// doi.org/10.1615/IntJMedMushrooms.2019030357 
13. Behera BC, Mishra R, Mohapatra MS (2021) Microbial citric acid: production, properties, application and future perspectives. Food Frontiers 2(1):62-76. https://doi.org/10.1002/fft2.66

14. Betiku E, Emeko HA, Solomon BO (2016) Fermentation parameter optimization of microbial oxalic acid production from cashew apple juice. Heliyon 2(2):e00082. https://doi.org/10.1016/j.heliyon.2016.e00082

15. Börekçi BS, Kaban G, Kaya M (2021) Citric acid production of yeasts: an overview. EuroBiotech J 5(2):79-91. https://doi.org/10.2478/ebtj-2021-0012

16. Cairns TC, Barthel L, Meyer V (2021) Something old, something new: challenges and developments in Aspergillus niger biotechnology. Essays in Biochemistry EBC20200139. https://doi.org/10.1042/EBC20200139

17. Cao FH, Li XJ, Luo SZ, Mu DD, Zhong XY, Jiang ST, Zheng Z, Zhao YY (2017) Effects of organic acid coagulants on the physical properties of and chemical interactions in tofu. LWT-Food Sci Technology 85:58-65. https:// doi.org/10.1016/j.lwt.2017.07.005

18. Carsanba E, Papanikolaou S, Fickers P, Erten H (2019) Screening various Yarrowia lipolytica strains for citric acid production. Yeast 36(5):319-327. https://doi.org/10.1002/yea.3389

19. Cavallo E, Charreau H, Cerrutti P, Foresti ML (2017) Yarrowia lipolytica: a model yeast for citric acid production. FEMS Yeast Res 17(8):fox084

20. Ciriminna R, Meneguzzo F, Delisi R, Pogliaro M (2017) Citric acid: emerging applications of key biotechnology industrial product. Chem Central J 11(1): $1-9$

21. Das I, Arora A (2017) Post-harvest processing technology for cashew applea review. J Food Engineering 194:87-98. https://doi.org/10.1016/j.ffoodeng.2 016.09.011

22. de Vries RP, Riley R, Wiebenga A, Aguilar-Osorio G, Amillis S, Uchima CA, Anderluh G, Asadollahi M, Askin M, Barry K, Battaglia E (2017) Comparative genomics reveals high biological diversity and specific adaptations in the industrially and medically important fungal genus Aspergillus. Genome Bio 18(1):1-45

23. Demain AL (2000) Microbial biotechnology. Trends Biotechnol 18(1):26-31. https://doi.org/10.1016/s0167-7799(99)01400-6

24. Dhillon GS, Brar SK, Verma M, Tyagi RD (2011) Recent advances in citric acid bio-production and recovery. Food Bioprocess Technol 4(4):505-529. https://doi.org/10.1007/s11947-010-0399-0

25. Dienye BN, Ahaotu I, Agwa OK, Odu NN (2018) Citric acid production potential of Aspergillus niger using Chrysophyllum albidum peel. Adv Bioscience and Biotechnology 9(4):190-203. https://doi.org/10.4236/abb.201 8.94013

26. Domsch KH, Gams W, Anderson TH (2007) Compendium of soil fungi, 2nd edn. Eching, IHV-Verlag, $672 \mathrm{p}$

27. Dutta A, Sahoo S, Mishra RR, Pradhan B, Das A, Behera BC (2019) A comparative study of citric acid production from different agro-industrial wastes by Aspergillus niger isolated from mangrove forest soil. Environ Exper Biol 17:115-122

28. Elegbede JA, Lateef A (2018) Valorization of corn-cob by fungal isolates for production of xylanase in submerged and solid state fermentation media and potential biotechnological applications. Waste Biomass Valorization 9(8): 1273-1287. https://doi.org/10.1007/s12649-017-9932-y

29. Elegbede JA, Lateef A, Azeez MA, Asafa TB, Yekeen TA, Oladipo IC Adebayo EA, Beukes LS, Gueguim-Kana EB (2018) Fungal xylanasesmediated synthesis of silver nanoparticles for catalytic and biomedical applications. IET Nanobiotechnology 12(6):857-863. https://doi.org/10.1 049/iet-nbt.2017.0299

30. Elegbede JA, Lateef A, Azeez MA, Asafa TB, Yekeen TA, Oladipo IC, Abbas SH, Beukes LS, Gueguim-Kana EB (2019) Silver-gold alloy nanoparticles biofabricated by fungal xylanases exhibited potent biomedical and catalytic activities. Biotechnol Prog 35(5):e2829. https://doi.org/10.1002/btpr.2829

31. Elegbede JA, Lateef A, Azeez MA, Asafa TB, Yekeen TA, Oladipo IC, Aina DA, Beukes LS, Gueguim-Kana EB (2020) Biofabrication of gold nanoparticles using xylanases through valorization of corncob by Aspergillus niger and Trichoderma longibrachiatum: antimicrobial, antioxidant, anticoagulant and thrombolytic activities. Waste Biomass Valorization 11(3):781-791. https:// doi.org/10.1007/s12649-018-0540-2

32. FAOSTAT (2019). http://www.fao.org/faostat/en/\#data/QC. Accessed 13 June 2021

33. Felix AKN, Martins JJ, Almeida JGL, Giro MEA, Cavalcante KF, Melo VMM, Pessoa ODL, Rocha MVP, Gonçalves LRB, de Santiago Aguiar RS (2019) Purification and characterization of a biosurfactant produced by Bacillus subtilis in cashew apple juice and its application in the remediation of oil- contaminated soil. Colloids Surf B: Biointerfaces 175:256-263. https://doi. org/10.1016/j.colsurfb.2018.11.062

34. Fu GY, Lu Y, Chi Z, Liu GL, Zhao SF, Jiang H, Chi ZM (2016) Cloning and characterization of a pyruvate carboxylase gene from Penicillium rubens and overexpression of the genein the yeast Yarrowia lipolytica for enhanced citric acid production. Mar Biotechnol 18(1):1-14. https://doi.org/10.1007/s1 0126-015-9665-5

35. Gil-Serna J, García-Díaz M, Vázquez C, González-Jaén MT, Patiño B (2019) Significance of Aspergillus niger aggregate species as contaminants of food products in Spain regarding their occurrence and their ability to produce mycotoxins. Food Microbiol 82:240-248. https://doi.org/10.1016/j.fm.2019.02 013

36. Gomaa MS, El-Sokkary ES, Refaey MM (2009) Using acidulants in making ricotta cheese from sweet and salted whey. J Food Dairy Sci 34(4):29372943. https://doi.org/10.21608/jfds.2009.112334

37. Gueguim-Kana EB, Oloke JK, Lateef A, Oyebanji A (2012) Comparative evaluation of artificial neural network coupled genetic algorithm and response surface methodology for modelling and optimization of citric acid production by Aspergillus niger MCBN 297. Chem Eng Trans 27:397-402

38. Han Y, Du J, Li J, Li M (2019) Quantification of the organic acids in hawthorn wine: a comparison of two HPLC methods. Molecules 24(11): 2150. https://doi.org/10.3390/molecules 24112150

39. Hesham AEL, Mostafa YS, AISharqi LEO (2020) Optimization of citric acid production by immobilized cells of novel yeast isolates. Mycobiology 48(2): 122-132. https://doi.org/10.1080/12298093.2020.1726854

40. Hu W, Chem JS, Liu J, Song Y, Wu Q, Li W (2016) Changes in the physiological properties and kinetics of citric acid accumulation via carbon ion irradiation via mutagenesis of Aspergillus niger. J Zhejiang Univ Sci B 17(4):262-270. https://doi.org/10.1631/jzus.B1500120

41. Hu W, Li WJ, Yang HQ, Chen JH (2019) Current strategies and future prospects for enhancing microbial production of citric acid. Appl Microbiol Biotechnol 103(1):201-209. https://doi.org/10.1007/s00253-018-9491-6

42. Jeyavishnu K, Thulasidharan D, Shereen MF, Arumugam A (2021) Increased revenue with high value-added products from cashew apple (Anacardium occidentale L.)_-addressing global challenges. Food Bioprocess Technol 14(6):985-1012. https://doi.org/10.1007/s11947-021-02623-0

43. Kareem SO, Akpan I, Alebiowu OO (2010) Production of citric acid by Aspergillus niger using pineapple waste. Malaysian J Microbiol 6(2):161-116

44. Karklin R, Ramina L, Raso R (1984) Factors affecting the isolation of ca-citrate from fermentation solution of n-alkanes. Biosint Oksikilot Ketokislot Mikroorg:43-51

45. Lateef A, Darwesh OM, Matter IA (2021) Microbial nanobiotechnology: the melting pot of microbiology, microbial technology and nanotechnology. In: Lateef A, Gueguim-Kana EB, Dasgupta N, Ranjan S (Eds.) Microbial nanobiotechnology: principles and applications. Springer Nature Singapore Pte, Singapore, pp 1-19. Ltd. ISBN 978-981-334-777-9. https://doi.org/10.1 007/978-981-33-4777-9_1

46. Lateef A, Oloke JK, Prapulla SG (2007) The effect of ultrasonication on the release of fructosyltransferase from Aureobasidium pullulans CFR 77. Enzym Microb Technol 40(5):1067-1070. https://doi.org/10.1016/j.enzmictec.2006. 08.008

47. Lateef A, Oloke JK, Gueguim-Kana EB, Raimi OR (2012) Production of fructosyltransferase by a local isolate of Aspergillus niger in both submerged and solid substrate media. Acta Aliment 41(1):100-117. https://doi.org/10.1 556/AAlim.41.2012.1.12

48. Lateef A, Oloke JK, Gueguim-Kana EB, Oyeniyi SO, Onifade OR, Oyeleye AO, Oladosu OC (2008) Rhizopus stolonifer LAU 07: a novel source of fructosyltransferase. Chem Pap 62(6):635-638

49. Li A, Pfelzer N, Zuijderwijk R, Brickwedde A, van Zeijl C, Punt P (2013) Reduced by-product formation and modified oxygen availability improve itaconic acid production in Aspergillus niger. Appl Microbiol Biotechnol 97(9): 3901-3911. https://doi.org/10.1007/s00253-012-4684-x

50. Li QZ, Jiang XL, Feng XJ, Wang JM, Sun C, Zhang HB, Xian M, Liu HZ (2016) Recovery processes of organic acids from fermentation broths in the biomass-based industry. J Microbiol Biotechnol 26(1):1-8. https://doi.org/1 0.4014/jmb.1505.05049

51. Magwaza LS, Opara UL (2015) Analytical methods for determination of sugars and sweetness of horticultural products-a review. Sci Hortic 184: 179-192. https://doi.org/10.1016/j.scienta.2015.01.001

52. Mgaya J, Shombe GB, Masikane SC, Mlowe S, Mubofu EB, Revaprasadu N (2019) Cashew nut shell: a potential bio-resource for the production of bio- 
sourced chemicals, materials and fuels. Green Chem 21(6):1186-1201. https://doi.org/10.1039/C8GC02972E

53. Ozdal M, Kurbanoglu EB (2019) Citric acid production by Aspergillus niger from agro-industrial by-products: molasses and chicken feather peptone. Waste Biomass Valorization 10(3):631-640. https://doi.org/10.1007/s12649-01 8-0240-y

54. Priya AD, Setty YP (2019) Cashew apple juice as substrate for microbial fuel cell. Fuel 246:75-78. https://doi.org/10.1016/j.fuel.2019.02.100

55. Prommajak T, Leksawasdi N, Rattanapanone N (2018) Optimizing tannin precipitation in cashew apple juice. Chiang Mai Univ J Natural Sci 17(1):1323

56. Rabelo MC, Fontes CP, Rodrigues S (2009) Enzyme synthesis of oligosaccharides using cashew apple juice as substrate. Bioresour Technol 100(23):5574-5580. https://doi.org/10.1016/j.biortech.2009.06.060

57. Roukas T, Kotzekidou P (2020) Pomegranate peel waste: a new substrate for citric acid production by Aspergillus niger in solid-state fermentation under non-aseptic conditions. Environ Sci Pollut Res 27(12):13105-13113. https:// doi.org/10.1007/s11356-020-07928-9

58. Salih DA, Yasin SR (2020) Palm dates as a source for isolation of Aspergillus niger to produce citric acid by submerged fermentation; kinetics study. IOP Conference Series: Materials Science and Engineering 928(2):022072. https:// doi.org/10.1088/1757-899X/928/2/022072

59. Sawadogo M, Tanoh ST, Sidibé S, Kpai N, Tankoano I (2018) Cleaner production in Burkina Faso: case study of fuel briquettes made from cashew industry waste. J Cleaner Production 195:1047-1056. https://doi.org/10.10 6/j.jclepro.2018.05.261

60. Sawant O, Mahale S, Ramchandran V, Nagaraj G, Bankar A (2021) Fungal citric acid production using waste materials: a mini-review. J Microbiol Biotechnol Food Sci 8(2):821-828

61. Schuster E, Dunn-Coleman N, Frisvad T, Van-Dijek P (2002) On the safety of Aspergillus niger. Appl Microbiol Biotechnol 59(4-5):426-435. https://doi.org/1 0.1007/s00253-002-1032-6

62. Sewalt V, Shanahan D, Gregg L, La Marta J, Carrillo R (2016) The generally recognized as safe (GRAS) process for industrial microbial enzymes. Ind Biotechnol 12(5):295-302. https://doi.org/10.1089/ind.2016.0011

63. Shankar T, Sivakumar T (2016a) Optimization of citric acid production using Aspergillus niger isolated from the leaf litter soil of Sathuragiri Hills. Univ J Microbiol Res 4(4):79-87. https://doi.org/10.13189/ujmr.2016.040401

64. Shankar T, Sivakumar T (2016b) Screening of citric acid producing fungi from the leaf litter soil of Sathuragiri Hills. Bioeng Biosci 4(4):56-63. https:/ doi.org/10.13189/bb.2016.040402

65. Sharma P, Gaur VK, Sirohi R, Larroche C, Kim SH, Pandey A (2020) Valorization of cashew nut processing residues for industrial applications. Ind Crop Prod 152:112550. https://doi.org/10.1016/.indcrop.2020.112550

66. Show PL, Oladele KO, Siew QY, Zakry FAA, Lan JC, Ling TC (2015) Overview of citric acid production from Aspergillus niger. Front Life Sci 8(3):271-283. https://doi.org/10.1080/21553769.2015.1033653

67. Silva JS, Mendes JS, Correia JAC, Rocha MVP, Micoli L (2018) Cashew apple bagasse as new feedstock for the hydrogen production using dark fermentation process. J Biotechnol 286:71-78. https://doi.org/10.1016/j. jbiotec.2018.09.004

68. Srinivasarao B, Ratnam BW, Subbarao S, Narasimharao M, Ayyanna C (2013) Ethanol production from cashew apple juice using statistical designs. J Biochem Microbial Technol 1:8-15

69. STATISTA (2021) Production of cashew nuts (in shell) worldwide from 2010 to 2019. https://www.statista.com/statistics/967702/global-cashew-nutproduction/. Accessed 13 June 2021

70. Taddia A, Brandaleze GN, Boggione MJ, Bortolato SA, Tubio G (2020) An integrated approach to the sustainable production of xylanolytic enzymes from Aspergillus niger using agro-industrial by-products. Preparative Bochem Biotechnology 50(10):979-991. https://doi.org/10.1080/10826068.2020.1 777425

71. Tan MJ, Chen X, Wang YK, Liu GL, Chi ZM (2016) Enhanced citric acid production by a yeast Yarrowia lipolytica over-expressing a pyruvate carboxylase gene. Bioprocess Biosyst Eng 39(8):1289-1296. https://doi.org/1 0.1007/s00449-016-1607-8

72. Tong Z, Tong Y, Wang D, Shi YC (2021) Whole maize flour and isolated maize starch for production of citric acid by Aspergillus niger: a review. Starch-Stärke, 2000014. https://doi.org/10.1002/star.202000014

73. Umemura K, Ueda T, Munawar SS, Kawai S (2012) Application of citric acid as natural adhesive for wood. J Appl Polymer Science 123(4):1991-1996
74. Upton DJ, McQueen-Mason SJ, Wood AJ (2020) In silico evolution of Aspergillus niger organic acid production suggests strategies for switching acid output. Biotechnol Biofuels 13(1):1-21

75. Vandenberghe LPS, Rodrigues C, De Carvalho JC, Medeiros ABP, Soccol CR (2017) Production and application of citric acid. In Current developments in biotechnology and bioengineering (pp. 557-575). Elsevier

76. White TJ, Bruns T, Lee S, Taylor J (1990) Amplification and direct sequencing of fungal ribosomal RNA genes for phylogenetics. In: Innis MA, Gelfand DH, Sninsky JJ, White TJ (eds) PCR protocols: a guide to methods and applications. Academic Press, New York, pp 315-322. https://doi.org/10.101 6/B978-0-12-372180-8.50042-1

77. Yang L, Lübeck M, Lübeck PS (2017) Aspergillus as a versatile cell factory for organic acid production. Fungal Biol Rev 31(1):33-49. https://doi.org/10.101 6/j.fbr.2016.11.001

78. Zakaria L (2020) Microscopic characterization of two black Aspergillus, A. niger and A. aculeatus from different substrates and indoor environment. Malaysian J Microscopy 16(2):30-36

79. Zulkifli NA, Zakaria L (2017) Morphological and molecular diversity of Aspergillus from corn grain used as livestock feed. HAYATI J Biosciences 24(1):26-34. https://doi.org/10.1016/j.hjb.2017.05.002

\section{Publisher's Note}

Springer Nature remains neutral with regard to jurisdictional claims in published maps and institutional affiliations.

\section{Submit your manuscript to a SpringerOpen ${ }^{\circ}$ journal and benefit from:}

- Convenient online submission

- Rigorous peer review

- Open access: articles freely available online

- High visibility within the field

- Retaining the copyright to your article

Submit your next manuscript at $\boldsymbol{\nabla}$ springeropen.com 